\title{
Correction to: Diabetes, cardiovascular disease and the microcirculation
}

\author{
W. David Strain ${ }^{1 *}$ and P. M. Paldánius ${ }^{2,3}$
}

\section{Correction to: Cardiovasc Diabetol (2018) 17:57 https://doi.org/10.1186/s12933-018-0703-2}

Following publication of the original article [1], it has been brought to our attention that the article in Ref. [72] was retracted in March 2019.

The authors suggested deleting the following statement in section 'The effect of anti-diabetes drugs on microcirculation' from the original publication, citing the retracted article. The overall conclusions of the review article are not affected by this erratum.

"In addition to anti-diabetes agents, statins were reported to improve endothelial dysfunction and microvascular reactivity in patients with T2DM and dyslipidaemia, suggesting positive outcomes on CV morbidity and mortality of these class of drugs [72]."

Furthermore, the affiliation of author Päivi Maria Paldánius has changed since the original publication. The updated affiliations are provided with this erratum.

\section{Author details}

'Diabetes and Vascular Research Centre, Institute of Biomedical and Clinical Science, University of Exeter Medical School, Royal Devon \& Exeter NHS Foundation Trust, Barrack Road, Exeter, UK. ${ }^{2}$ Novartis Pharma AG, Basel, Switzerland. ${ }^{3}$ Research Group for Clinical and Molecular Metabolism (CAMM), Children's Hospital, Helsinki University Hospital (HUS), Helsinki University, Helsinki, Finland.
Published online: 11 June 2021

\section{Reference}

1. Strain WD, Paldánius PM. Diabetes, cardiovascular disease and the microcirculation. Cardiovasc Diabetol. 2018;17:57. https://doi.org/10.1186/ s12933-018-0703-2.

2. Kim KM, Jung KY, Yun HM, Lee SY, Oh TJ, Jang HC, Lim S. Effect of rosuvastatin on fasting and postprandial endothelial biomarker levels and microvascular reactivity in patients with type 2 diabetes and dyslipidemia: a preliminary report. Cardiovasc Diabetol. 2017;16(1):146. https://doi.org/ 10.1186/s12933-017-0629-0

\section{Publisher's Note}

Springer Nature remains neutral with regard to jurisdictional claims in published maps and institutional affiliations. adaptation, distribution and reproduction in any medium or format, as long as you give appropriate credit to the original author(s) and the source, provide a link to the Creative Commons licence, and indicate if changes were made. The images or other third party material in this article are included in the article's Creative Commons licence, unless indicated otherwise in a credit line to the material. If material is not included in the article's Creative Commons licence and your intended use is not permitted by statutory regulation or exceeds the permitted use, you will need to obtain permission directly from the copyright holder. To view a copy of this licence, visit http://creativecommons.org/licenses/by/4.0/. The Creative Commons Public Domain Dedication waiver (http//creativecommons.org/publicdomain/zero/1.0/) applies to the data made available in this article, unless otherwise stated in a credit line to the data. 